\title{
SEED VIABILITY OF OIL CROPS DEPENDING ON STORAGE CONDITIONS
}

\author{
Balešević-Tubić, S. , Tatić, M., Đorđević, V., Nikolić, Z. and Đukić, V.
}

Institute of Field and Vegetable Crops, M. Gorkog 30, 21000 Novi Sad, Republic of Serbia

Received: July 01, 2009

Accepted: April 03, 2010

SUMMARY

\begin{abstract}
Changes occurring in seed during aging are significant as far as seed quality and longevity are concerned and are a consequence of the effects of different storage conditions. The chemical composition of seed with high oil content is related to specific processes occurring in seed during storage. In this trial, sunflower and soybean genotypes developed in Novi Sad were submitted to accelerated aging for three and five days, and natural aging for six and twelve months, under controlled and conventional (non-controlled) conditions. The obtained results showed that preservation of seed viability depended on storage condition and duration, as well as plant species. Accelerated aging test can be used to predict the length of storage life of sunflower and soybean seed. In comparison to sunflower seed, soybean seed is more sensitive to damage and reduced germination during storage.
\end{abstract}

Key words: sunflower, soybean, seed, aging, germination

\section{INTRODUCTION}

Changes that occur in seed during aging are significant in terms of seed quality, the feature that, among other things, also implies seed longevity (Milošević and Malešević, 2004). Progress of the technology and industrialization of agricultural production has increased opportunities for long term storage of seed (Lekić, 2003). The purpose of storage is to maintain harvest quality of product, not to improve it (Sisman and Delibas, 2004). The rate at which the seed aging process takes place depends on the ability of seed to resist degradation changes by protection mechanisms which are specific for each plant species (Balešević-Tubić, 2001). Kept under the same storage conditions, seeds of different plant species lose viability to a various degree. For example, onion seed is very difficult to store, while barley seed maintains good germination under a variety of storage conditions (Milošević et al., 1996). The chemical composition of oilseeds causes specific processes to occur

* Corresponding author: e-mail: svetlanabt@ifvcns.ns.ac.rs 
during storage. The seeds rich in lipids have limited longevity due to their specific chemical composition. For example, sunflower seed storage demands special attention due to high oil content, otherwise processes may occur that lead to loss of germination ability and seed viability (Christensen, 1971; Balešević-Tubić et al., 1999; Balešević-Tubić et al., 2007a).

Some researchers believe that survival of plants in adverse field conditions can be reliably predicted on the basis of laboratory germination tests. Others maintain that small differences in germination percentage can sometimes overshadow large differences existing in seed damage rate (Milošević and Ćirović, 1994). The same authors suggested that under adverse conditions such as the temperature above $30^{\circ} \mathrm{C}$ and relative air humidity from 80 to $90 \%$ the variation in seed germination rate can be high. It seems that temperature, moisture and storage duration are the most important individual factors which affect on stored product quality and quantity (Sisman, 2005).

Accelerated aging of seed, i.e., seed lot exposure to high temperature and high relative humidity leads to a loss of vigor and eventually to a loss of viability. It is an excellent method for determination of changes in vigor during seed storage (Tian et al., 2008). An accelerated aging test showed that the aging seed is characterized by the loss of germination, reduced germination rate and poor seedling development (Lekić, 2003; Tatić et al., 2008). Fabrizius et al. (1999) confirmed the possibility of predicting the actual germination rate of soybean seed during natural aging by applying the accelerated aging test, the main factors being the time of natural aging duration and degree of seed deterioration.

The objectives of this study were to determine how different seed storage methods and storage times affected the germinability of diferent oil crops and to examine the possibility of using the accelerated aging test for the assessment of reduced or preserved seed viability over time.

\section{MATERIALS AND METHODS}

The seed of five sunflower lines and six soybean varieties developed at Institute of Field and Vegetable Crops, Novi Sad, was submitted to accelerated and natural aging.

Accelerated aging. The seed was placed in metal dishes, on metal sieves immersed in a water bath at $42^{\circ} \mathrm{C}$ and relative humidity of $100 \%$. The test lasted three and five days.

Natural aging. Seed was stored in two ways. One part was kept in a cool chamber (controlled conditions), at $4^{\circ} \mathrm{C}$ and relative air humidity of 80 to $85 \%$, another was kept under conventional storage conditions (non-controlled conditions). Seed characteristics were tested after six and 12 months of storage. 
Germination of fresh and artificially and naturally aged seed was estimated by the standard laboratory germination test, according to the Rules of International Seed Testing Association (ISTA, 1999). The results of the treated seed were compared with the germinability of fresh seeds (measured at the start of the experiment and used as the control treatment).

Statistical analysis. Mean comparison (t-test) and simple linear regression tests were done using the statistical software Statisica8. All values represented in this paper are averages over four replications.

\section{RESULTS AND DISCUSSION}

Concerning the duration of storage, reduced germination was observed in all sunflower genotypes, which was particularly significant after 12 months of storage (Figure 1). The above-mentioned results revealed that some changes leading to decreased germination occurred also during natural sunflower seed aging. It is worth mentioning that the seed germination of the tested sunflower lines declined more in the seed stored under conventional conditions than that stored under controlled conditions. Changes leading to decreased germination occurred in sunflower seed during storage under conventional conditions due to high oil content (Beratlief and Iliesku, 1997). These authors stated that optimal conditions for sunflower seed storage and effective prevention of seed deterioration were a temperature below $10^{\circ} \mathrm{C}$, and a relative air humidity up to $70 \%$. According to Ghasemnezhad and Honermeir (2007), the storage life of sunflower seed can be reduced by long storage and high storage temperature.

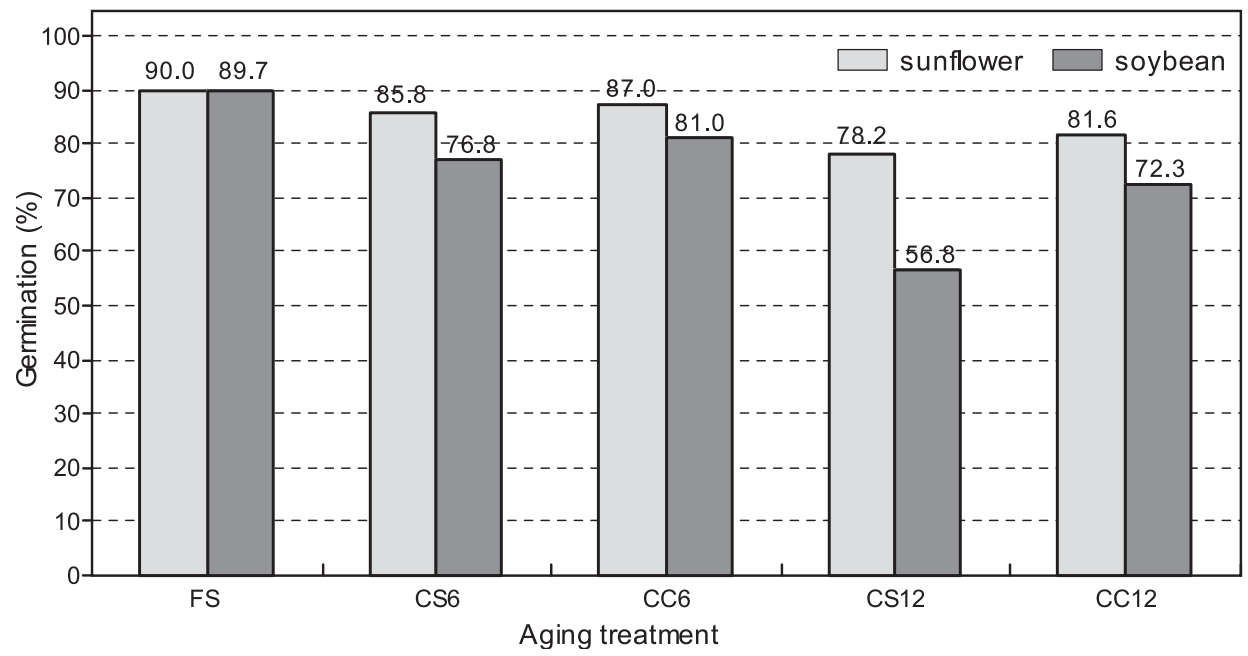

Figure 1: Changes in seed germination of sunflower and soybean genotypes under different storage conditions and duration (FS-fresh seed; CC-controlled conditions and CS-conventional storage, measured after 6 and 12 months) 
It is important to note that the seed germination of the studied soybean genotypes declined more in the seeds stored under conventional conditions, due to variability in temperature and relative humidity (Figure 1), than in the seeds stored under controlled conditions. The results provided futher proof that, in addition to cultivar, storage conditions, and duration were significant factors affecting the germination rate of soybean seed. Similar results were obtained by Nugraha and Soejadi (1991) for soybean seed stored for six months under conventional conditions. They stated that in a group of tested varieties only one maintained germination above $80 \%$.

The tested sunflower and soybean genotypes had similar initial seed germination rates, 90 and $89.7 \%$, respectively. However, decline in seed germination after six and twelve months of storage was more pronounced in the soybean genotypes, especially under conventional conditions (by $14.1 \%$ and $36.4 \%$, respectively), than in the sunflower genotypes. The obtained results indicated that the soybean seed was significantly more sensitive to the length of storage, as well as to storage conditions, than the sunflower seed. Sunflower seed was much more stable in terms of storage duration, and the decrease in germination rate after 12 months of storage was approximately equal to the decrease in germination rate of soybean genotypes after six months of storage, both under controlled $181.6 \%$ for sunflower germination, $81.0 \%$ for soybean germination, respectively), and under conventional conditions $\mathbf{2 7 8 . 2 \%}$ for sunflower germination, $76.8 \%$ for soybean germination, respcetively).

Different longevity of seed storage as well as storage conditions exert significant influence on seed germination (Nkang and Umoh, 1997). The results of Sharma (1977) clearly pointed out to declining trends in total oil content and seed germination during storage of oilseed species. Seed aging during storage is an inevitable phenomenon, but the degree and speed of decline in seed quality depend strongly, beside storage conditions, on plant species stored and initial seed quality (Elias and Copeland, 1994; Balešević-Tubić et al., 2005) as well as on seed genetic traits (Malenčić et al., 2003). Milošević et al. (1996) suggested too that seed longevity is genetically determined, and that significant differences exist among cultivars of the same crop in their ability of quality maintenance during storage. Therefore, they suggested that the longevity of seed can be improved by appropriate breeding procedures.

Artificial aging of sunflower and soybean seed cause a significant reduction in the seed germination rate. Seed germination of the sunflower lines submitted to accelerated aging for three days (Figure 2) was approximately equal to the seed germination rate measured after 12 months of natural aging $\left(\mathrm{R}^{2}=0.93\right)$, while in soybean genotypes a high similarity existed in seed germination rates after five days of artificial aging and seed storage for 12 months under conventional conditions $\left(\mathrm{R}^{2}=0.92\right)$. A comparison of germination rate decline after artificial aging and storage under conventional conditions revealed that the sunflower seed was more 
resistant to stress conditions than the soybean seed. The soybean seed subjected to extreme conditions of accelerated aging for five days suffered stress that was comparable to that suffered by 12 monhts of natural aging. This indicates that, in soybean seed, adverse processes were more intensive, and that it why it was more difficult to store soybean seed than sunflower seed. The obtained results confirmed the view that the application of the accelerated aging test can serve for predicting the response of seed to a certain period of natural aging. The possibility to gain a quick insight into changes in seed that would occur after a specific period of storage under conventional conditions enable the prediction of optimal conditions for storing the seed and preventing damage and deterioration of seed during storage (Balešević-Tubić et al., 2007b). The symptoms observed during accelerated ageing can be used to characterize the extent of aging, which changes in the opposite direction of that followed by storability (Smith and Berjak, 1995).
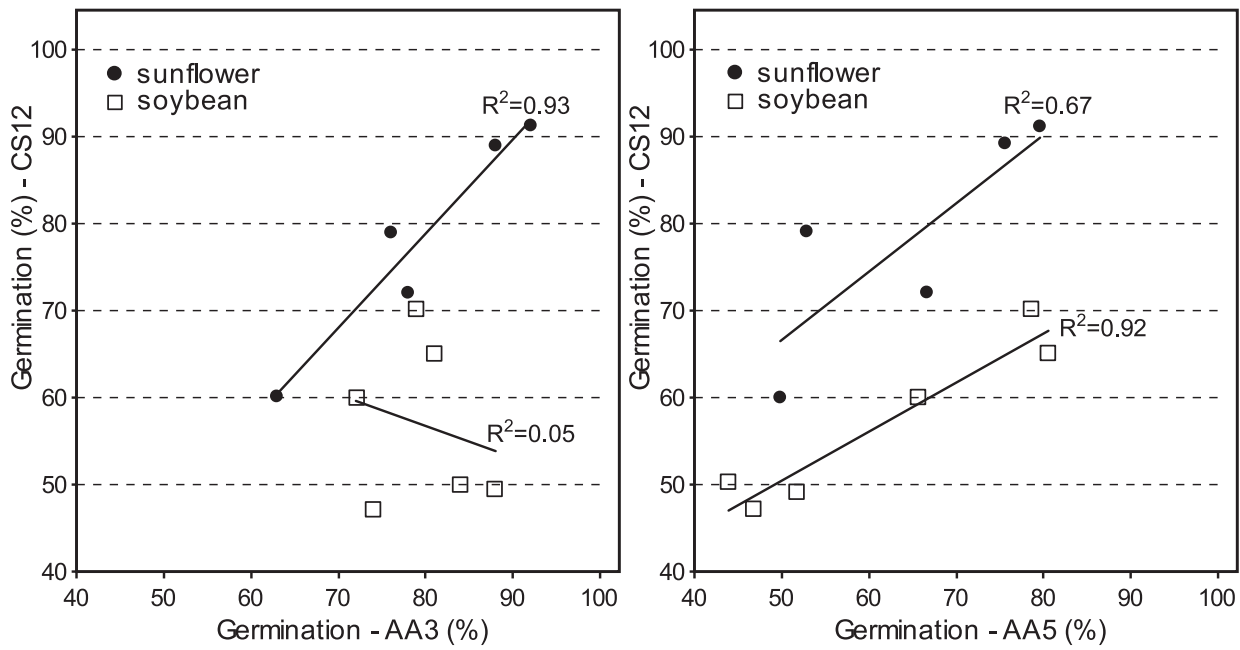

Figure 2: Prediction of seed germination during natural aging of sunflower and soybean seed based on accelerated aging test (CS12-conventional storage after 12 months; AA3-accelerated aging test for 3 days; AA5- accelerated aging test for 5 days)

The above-mentioned results were in accordance with the results obtained by Milošević et al. (1995), according to which the germination of sunflower seed submitted to accelerated aging declined by $14 \%$, and of soybean seed as much as $50 \%$. Results of Fabrizius et al. (1999) confirmed a possibility of using accelerated aging test to predict seed storability. After one year of soybean seed storage, two of the seven tested lots had the germination rate below $80 \%$ (germination of the remaining lots was over $90 \%$ ). The germination rate predicted by using accelerated aging of seed, for all lots, varied within $10 \%$ of the actual germination rate. 


\section{CONCLUSIONS}

Seed aging, both artificial and natural, caused damage to the seed, which negatively affected the quality, i.e., seed germination rate of the tested sunflower and soybean genotypes. Degree of damage and ability of seed to resist negative effects of aging were under the effect of storage duration, type of storage, and agricultural crop in question.

Effectes of the accelerated aging tests on changes in sunflower and soybean seeds have proved that the degree of seed deterioration during natural aging, and seed storability can be predicted in laboratory.

The best way of seed storage is the one that causes smallest changes in the biological nature of seed, which can be acomplished by appropriate regulation of relative air humidy and temperature. Even the most sensitive seed will retain a high level of viability for several years if stored with a low moisture content and at a low temperature. Regardless of the problems ensuing from the lack of adequate storage facilities, one must always keep in mind that seed is a living organism whose biological quality may deteriorate, especially in the case of oil seeds.

\section{REFERENCES}

Balešević-Tubić, S., Milošević, M., Zlokolica, M., Nikolić, Z., Vujaković, M., 1999. Uticaj uslova skladištenja na biohemijske promene u semenu uljanih biljnih vrsta. Procesna tehnika i energetika u poljoprivredi 3(1-2): 20-24.

Balešević-Tubić, S., 2001. Uticaj procesa starenja na životnu sposobnost i biohemijske promene semena suncokreta. Doktorska disertacija, Poljoprivredni fakultet, Novi Sad.

Balešević-Tubić, S., Malenčić, Đ., Tatić, M. and Miladinović, J., 2005. Influence of aging process on biochemical changes in sunflower seed. Helia 28(42): 107-114.

Balešević-Tubić, S., Tatić, M., Miladinović, J., Pucarević, M., 2007a. Changes of faty acids content and vigour of sunflower seed during natural aging. Helia 30(47): 61-67.

Balešević-Tubić, S., Tatić, M., Hrustić, M., Miladinović, J., Maksimović, L., 2007b. The influence of aging process on germination and seedling growth of sunflower seed. In: Proceedings of The First Joint PSU-UNS International Conference on BioScience: Food, Agriculture, and the Environment, Thailand: 198-202.

Beratlief, C., Iliescu, H., 1997. Highlights of proper sunflower seed storage. Helia 20(26): 121137.

Christensen, C.M., 1971. Evaluating conditions and storability of sunflower seeds. J. Stored Prod. Res. 7: 163-169.

Elias, S.G., Copeland, L.O., 1994. The effect of storage conditions on canola (Brassica napus L.) seed quality. Journal of Seed Technology 18: 21-22.

Fabrizius, E., TeKrony, D., Egli, D.B., Rucker, M., 1999. Evaluation of a viability model for predicting soybean seed germination during warehouse storage. Crop Sci. 39: 194-201.

Ghasemnezhad, A., Honermeier, B., 2007. Influence of storage conditions on quality and viability of high and low oleic sunflower seeds. International Journal of Plant Production 3(4): 41-50.

ISTA, 1999. International Rules for Seed Testing. International Seed Testing Association, Switzerland.

Lekić, S., 2003. Vigour of seed. Association of breeders and seed researchers of Serbia, Belgrade.

Malenčić, Đ., Popović, M. and Miladinović, J., 2003. Stress tolerance parameters in different genotypes of soybean. Biology Plantarum 46: 141-143.

Milošević, M., Ćirović, M., 1994. Seme. Institut za ratarstvo i povrtarstvo, Novi Sad: 79-82. 
Milošević, M., Malešević, M., 2004. Semenarstvo. Naučni institut za ratarstvo i povrtarstvo, Novi Sad: 110-114.

Milošević, M., Rajnpreht, J., Graovac, M., Zlokolica, M., 1995. Uticaj starenja na osnovu pokazatelja životne sposobnosti semena važnijih ratarskih biljnih vrsta. Agronomska saznanja 3: 2-5.

Milošević, M., Ćirović, M., Mihaljev, I., Dokić, P., 1996. Opšte semenarstvo, Feljton, Novi Sad, 148-153.

Nkang, A., Umoh, E.O., 1997. Six month storability of five soybean cultivars as influenced by stage of harvest, storage temperature and relative humidity. Seed Sci. and Technol. 25: 93-99.

Nugraha, U.S., Soejadi, S., 1991. Evaluation on seed storability on soybean genotypes. Indon. J. Crop Sci. 6: 1-10.

Sharma, K.D., 1977. Biochemical changes in stored oil seeds. Indian J. Agri. Res. 11(3): 137141.

Sisman, C., Delibas, L., 2004. Storing sunflower seed and quality losses during storage. Journal of Central European Agriculture 4: 239-250.

Sisman, C., 2005. Quality losses in temporary sunflower stores and influences of storage conditions on quality losses during storage. Journal of Central European Agriculture 6: 143-150.

Smith, M.T., Berjak, P., 1995. Deteriorative Changes Associated with the Loss of Viability of Stored Desiccation-Tolerant and Desiccation-Sensitive Seeds. In: Kigel, J. and Galili, M.G. (Eds) Seed Development and Germination, New York, Marcel Dekker, pp. 701-746.

Tatić, M., Balešević-Tubić, S., Vujaković, M., Nikolić, Z., 2008. Changes of germination during natural and accelerated aging of soybean seed. In: Proceedings of The Second PSU-UNS International Conference on BioScience: Food, Agriculture and Environment, Serbia, 256-259.

Tian, X., Song, S., Lei, Y., 2008. Cell Death and Reactive Oxigen Species Metabolism during Accelerated Ageing of Soybean Axes. Russian Journal of Plant Physiology 55 (1): 33-40. 